\title{
Energy, Security, and Foreign Policy
}

\author{
Özgür Özdamar \\ University of Economics and Technology, Ankara
}

\begin{abstract}
Introduction
Many aspects of modern life, economies, and the relations between states are shaped by the development of energy resources and technologies. The reliance on energy in every field of life has made energy security tremendously important for states and societies. Especially for modern militaries, securing energy resources has become of utmost importance since the beginning of the twentieth century. Therefore, "second only to national defense," energy security has become a primary concern for the survival and wellbeing of both developed and developing nations (Hamilton 2005:xxi).

For some historians, twentieth century history was greatly determined by First Lord of Admiralty Winston Churchill's decision that the British Navy must switch from using coal to petroleum to maintain its hegemony before World War I. This decision shaped the course of the war; it also led the Allies to invade the oil-rich territories in the Middle East. Energy resources were even more important in World War II. One of the major reasons that Japan attacked the US was the latter's oil embargo against the former's empire. The Axis powers, lacking substantial energy resources, based their strategies on first gaining access to energy-rich areas, such as Romania and the Caspian Sea. The Allies, on the other hand, "floated to victory on a sea of oil" and used nuclear power for the first time to conclude the war (Barton et al. 2004:3).

The modern concern with energy security began with the Arab-Israeli war of 1973-4 and the Organization of Arab Petroleum Exporting Countries (OAPEC) and Organization of Petroleum Exporting Countries (OPEC)'s use of the "oil weapon." OPEC's boycott of major energy-importing countries in Europe and the US has shown how important it is for modern societies to secure their supply of energy; it became clear that an energy crisis can hurt everyone in society, including government, business, and individuals. Consequently, securing energy resources has become a key aspect of foreign policy making since the 1970s.

With the collapse of the Soviet Union in 1991, the concerns for energy security acquired a new dimension: The newly independent energy-rich ex-Soviet republics in the Caspian basin have become a playground for great-power rivalry. The US and EU, both having suffered from dependency on Middle Eastern energy in the 1970s, have begun increasing their political and economic influence on the region to gain access to energy resources. "The New Great Game" was coined as a term to describe the rivalry between the Western powers and a weakened Russia for the control of the Eurasia region and its energy resources (Kleveman 2003). Since energy-hungry China has begun pursuing aggressive foreign policies to secure the supply of energy to its growing market, this rivalry has taken a "tripolar" shape.

Owing to these current concerns in public policy, some academic research focused on studying the subject of energy security. These studies produced various definitions of the concept with differing components. We present a definition that is comprehensive and in conjunction with the latest developments on the global energy markets.
\end{abstract}


Energy security can be defined as a condition in which a nation and all (or most) of its citizens and industries have access to adequate energy resources at reasonable prices for the foreseeable future, free from serious risks of major disruption of service (Hancher and Janssen 2004). Insecurity can arise from various causes, such as geopolitical instability, natural disasters, terrorism, poor regularity designs, or a lack of investments (Redgwell 2004). This review's focus is political economic sources of energy (in) security. This definition was also chosen because it underlines the integrated nature of national security and energy policy. In political science, this approach forms a bridge between security and international political economy (IPE) studies.

The literature on energy security suggests that different countries have developed different strategies for securing their energy supply. The UN-mandated and US-led coalition's campaign to secure Kuwaiti sovereignty in 1990 and 1991 can be understood within this context. The US and others prevented Iraq from becoming the second-largest oil producer in the world, controlling the Persian Gulf transit and threatening Saudi Arabia, the largest oil producer, militarily. It is also argued that the US and UK's military intervention in Iraq in 2003 can be evaluated in this context. As the argument goes, especially after the 9/11 attacks, the nature of US-Saudi relations has become ambiguous in ways that might have led the US and UK to unlock the Iraqi oil potential for world markets by removing the Baath regime.

Alternatively, the EU, perhaps owing to its lack of military power and a common foreign policy, has taken a more multilateralist, economic incentives oriented approach to the problem of energy security. The EU Commission's Green Paper (2000) outlined an energy strategy for the following 20 years that aims toward ensuring the wealth of its citizens and economies and guaranteeing the uninterrupted physical availability of energy products on the market at an affordable price, while respecting environmental concerns and looking toward sustainable development (Hancher and Janssen 2004).

As the European Commission's Green Paper (2000) suggests, there are two general problems associated with this long-term strategy: a) finding a balanced approach between controlling demand and economic development, and b) ensuring the supply from Russia, CIS, and the Middle East, which requires foreign policy initiatives by the EU.

From the security studies and IPE perspective, there is a substantial vacuum in the literature dealing with energy security, in terms of the number of studies, theory development, and use of advanced methodological approaches developed in the discipline. Energy security literature lacks the intellectual give-and-take both within political science and with other disciplines, such as economics. A review of the literature by Wilson (1987) shows only a few review articles and some monographs that discuss the question which international relations (IR) paradigm most sufficiently explains the processes of the world energy markets. The literature has not improved significantly since Wilson wrote his review, particularly because of the relative stability of the world oil markets in the 1990s and early 2000s. There is a void in the literature to be filled with new theoretical and methodological approaches to the study of energy security.

Studies from various fields, such as neoclassical economics, public economics, political economy, and foreign policy analysis, are reviewed in conjunction with an analysis of their most studied research questions, key variables, policy prescriptions, and contribution to the overall study of energy security.

\section{Literature and its Limitations}

This essay presents a review of literature on energy security. It is rather difficult to categorize a literature so unsystematic and desultory, lacking theoretical development 


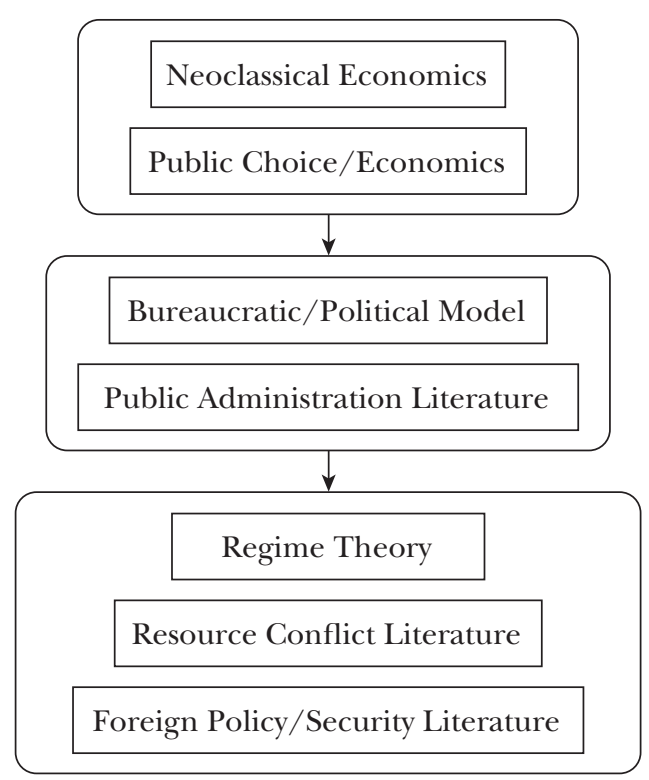

Figure 1 Energy security theories (from strictly economic to decision making oriented)

in a cumulative way. It aims to clarify the logic and contribution of different streams of literature and is organized according to the following criteria: 1) a summary of the major research questions, key variables, and policy prescriptions of each approach, and 2) a threefold distinction between strictly economic, administrative decision making, and foreign policy oriented studies, i.e., progressing from the micro to the macro level. First, economic theories are reviewed, then decision making-bureaucratic politics approaches, and lastly political economy and foreign policy-national security studies that emphasize macro structures as well as micro variables are discussed (see Figure 1). More specifically, based on a discussion of the energy literature and its limitations, the theoretical approaches that are suited to answering the posed research questions will be discussed (i.e., approaches that can help overcome some of the difficulties that previous research has faced.)

Joseph Nye (1982:121) suggests that "academic fashions in political science often reflect current concerns in public policy." The literature on energy security is an example of that. After the 1973-4 and 1979 oil crises, political scientists and economists produced various works approaching the subject from different perspectives. However, this literature has been resistant to conceptual rigor and theoretical development. Various works based on different theoretical and methodological perspectives were not successful in adequately conceptualizing the issue at hand, which is fundamental to the new international patterns of power and economic relations. The literature on energy security has been unselfconscious and uncritical in the following regards pinpointed by Ernst J. Wilson:

There is little if any sustained intellectual give-and-take in the field of international energy policy studies over the most appropriate ways to analyze the phenomenon. A thorough search of the literature reveals only a mere handful of review articles or monographs which seriously debate the relative explanatory power of competing paradigms for the world oil market. Given the immense practical importance of the subject and the interest shown by social scientists, and in light of potential intellectual payoffs, the quality of theoretical literature is meager at best. A void exists at what should be the center of the field. (Wilson 1987:126) 
This trend in the literature has not changed since Wilson wrote that paragraph more than two decades ago. With the end of the Cold War and the relative stability of energy markets in the 1990s, there has been almost no theoretical development in the literature dealing with energy security. Therefore, there is a great opportunity for political scientists to contribute to theory development. IPE literature studies trade, finance, aid, foreign investment, and economic coercion, but the subject of energy from a security perspective has not been a priority in the field.

This leads to important intellectual consequences. First, the theoretical background of the field makes it impossible to measure intellectual progress beyond collecting raw data. Second, as a result of lacking self-criticism, the research agenda does not show progress as a "scientific research enterprise" in James's (2002) terms. In other words, the disorganized nature of the research prevents scholars from prioritizing the issues to be studied (Wilson 1987). Despite the lack of organization of the literature, it can be split into three general sections: neoclassical economics and public choice, policy and political models, and political economy.

\section{Neoclassical Economics and Public Choice Literature}

Economists have studied energy markets extensively. The paradigm they worked with is based on the organizing principles of neoclassical economics. That is, the basic laws of supply and demand determine the behavior of energy markets: Supply and demand meet in the market and operate in equilibrium. The prices of oil, natural gas, or other resources will be determined by where the forces of supply and demand meet. Political variables are generally attributed to be intervening variables or to causing market externalities.

Externality refers to an external economy (diseconomy), an event that grants an appreciable benefit to a person or group who were not fully included in the decision process that led directly or indirectly to the event in question (Cornes and Sandler 1996). There is a substantial body of public economics literature that focuses on energy market externalities. Bohi and Toman $(1995 ; 1996)$ classify literature that focuses on energy market externalities under four categories: studies dealing with OPEC and its market power, the US's monopsony power, indirect costs of market power, and the relationship between oil import costs and military expenditures.

Adelman's (1972) World Petroleum Market is a classic example of neoclassical economics literature on energy security. According to Adelman, the government has no say in providing oil markets with stable prices. The invisible hand of the market determines the prices and outputs. The government's effort to stabilize prices is a waste of time and resources, according to this point of view, and exporting countries are less likely to cut back their production for political reasons (Wilson 1987). This deterministic description and explanation of energy markets proved to be incorrect with regard to the two successive crises within six years during the 1970s.

Adelman's other works $(1974 ; 1980 ; 1990 ; 2004)$ also extensively focused on OPEC's market power. In many of his articles he argues that OPEC has exercised market power and acted as a cartel, although a "clumsy" one, as he acknowledges. For the past two-and-a-half decades Adelman has argued that the real threat to the world oil market is OPEC's clumsiness and shortsightedness. He argues that there is an unexplainable gap between oil prices and the marginal cost of oil supply. The difference is, of course, the monopoly profit. In his 1974 article, which was published about six months after the 1973 oil crisis, he claims that OPEC created a producers' monopoly, which was possible owing to lack of cooperation from US allies. Ultimately, he does not believe in the idea of an "oil weapon" but thinks that there is too little cooperation among consumers to contain the cartel. But he subscribes to the view 
that producers and consumers cannot take the risk of alienating each other. His solution to attempts to blackmail Western economies is simple: "We need only tell the Saudis their embargo on shipments to us is henceforth permanent, their status having been canceled by their own act" (Adelman 1974:66).

In a similar study, Kennedy (1974) argues the same way, but from a different point of view. Kennedy claimed that OPEC acts like a cartel but to a limited degree. $\mathrm{He}$ concludes that the price peak in 1973 couldn't be maintained because the largest producing region, i.e., the Middle East and North Africa, would have a problem allocating the reduced output among the member countries. In retrospect, his predictions turned out to be accurate. It is obvious that OPEC has the capability to influence oil prices. However, economists and political economists tend to disagree to what extent and how, because OPEC does not act like a typical price-setting cartel (Bohi and Toman 1995). There is disagreement on whether OPEC can really apply market power. MacAvoy (1982), for instance, suggests that the price crises of the 1970s could have happened even if OPEC had not acted the way it did, for those peaks were the results of increasing demand and specific international political crises. Griffin (1985), on the other hand, tests alternative hypotheses about the question of OPEC's market power and finds that the organization appears to be a partial market-sharing cartel. OPEC members' outputs are sensitive to demands of individual consumers, but the output changes are not strictly proportional (Griffin 1985; Bohi and Montgomery 1982).

The second type of market externality that Bohi and Toman (1995 and 1996) analyze is the US monopsony position in the market. They argue that the US as a whole can be a monopsony power. The question is whether the US can retaliate against OPEC if the latter uses its seller's power. As the quotation above implies, Adelman thinks the US does have ways to exercise retaliation. Other economists argue that such a step would not be efficient in decreasing the price of oil (Broadman and Hogan 1988).

Third, the literature studied the indirect costs of market power. The argument is that higher oil prices turn into depreciation in dollar, and oil prices put pressure on inflation. Both ideas are discussed extensively and there are examples from both sides of the discussion. James D. Hamilton (1983), for instance, suggests that in the period from 1948 to 1972, all but one of the recessions in the US were preceded by a dramatic increase in the price of crude oil petroleum. He shows that a correlation between the price of oil and recession is significant and that it is not spurious that oil shocks are contributing factors in at least some of the recessions the US faced prior to 1972. Hubbard (1986) reaches the same conclusion: Even transitory shocks exhibit persistence effects on long-term prices, although he acknowledges that the persistence of shocks also depends on the structure of the given economy. On the other hand, other studies argued that the effect of oil price shocks or increased inflation is exaggerated. Eastwood (1992) shows that the effect of oil prices on US inflation might be overstated. In a similar study, Kibritçioğlu and Kibritçioğlu (1998) argue that the effect of crude oil price increases on inflation in Turkey is insignificant.

Fourth, it has frequently been argued that substantial military expenditures, such as in the Middle East, add to the social costs of oil imports. Although this argument is popular in mass media and public discourse, Bohi and Toman (1995) say that it rests on several logical and practical mistakes. First, they argue, these expenditures are the costs of mitigating energy security and not a cost of insecurity itself. Also, the expenditures are made to accomplish many security goals, not only the security of energy. Last, assigning premiums to oil imports is logically and mathematically wrong for different reasons: The military expenditures are made to prevent damage to total energy consumption, so the unit cost should reflect such a big denominator. Also, the US's military presence in energy-rich regions is good for many allies, not only for the US. For all of these reasons, Bohi and Toman (1995) argue that the cost of a 
military expenditure premium on oil should be sharply reduced and the subject should not be neglected.

Finally, some of the literature on energy economics is devoted to the examination of the relationship between oil price hikes and oil investment and developments (Brennan and Schwartz 1985; Dixit and Pindyck 1994). This research focuses on the question of what time is economically optimal for energy companies to invest. This question is related to the energy security of nations; more investment means more spare capacity and more sellers in the market. In a very interesting study, Miller and Zhang (1996) argue that according to the theory of irreversible investment, the development of an oil field should take place when a unique "price trigger" is passed. They study the 1990-1 Gulf War and its effects on prices in the UK. They found that in order to conduct a more thorough analysis, they need to incorporate large transitory price hikes (i.e., during the Gulf War), evaluate the profitability of an oil field contingent on war and peace, and calculate separate triggers in both cases. They find that the switch between these two triggers is about three-fourths of the price hike caused by the war. Therefore, they argue that only a quarter of the price hike should be accounted for by calculating the cost of an oil field, because the prices fall back by about three-fourths after the war.

A general evaluation of energy security externalities and neoclassical economics literature on energy is that they advanced our knowledge of identifying different externalities that cause energy markets to fail to internalize all costs and benefits. However, empirical evidence on these externalities is not dependable and more research is required to observe the causal effects of externalities on energy market fluctuations and trade (Bohi and Toman 1995). Although this literature is useful with respect to capturing the dynamic nature of energy markets, the occasional exclusion of political and institutional variables constitutes its weaknesses. In the long run, the main element determining energy prices and supply is most probably the market; in terms of short-term influences, however, political variables proved to be of the utmost importance (Wilson 1987). In addition, economics literature seems to subscribe to the assumption that oil will not "peak" in the future. However, the so-called "Hubbert's Peak" perspective suggests that world oil will "peak" sometime at the beginning of the twenty-first century and then drop steadily thereafter (Deffeyes 2005). Such a scenario would change everything assumed and hypothesized about energy security by both economists and political scientists.

\section{Bureaucratic Politics Model and Public Administration Literature}

Bureaucratic politics (Miller 1977; Greenberger 1983) models represent the second group of studies analyzing energy security. These models are concerned with where markets and domestic politics meet. Authors focus on elite decision making, emphasizing the role of power, leadership, interests and the markets, short-term volatilities, production levels, prices, and the decisions shaping them (Wilson 1987).

Stephen Krasner (1978), for instance, explains whether the short-term push and pull of business interests shapes the national interest of the US in the energy policy sector. He claims that the White House and State Department are relatively independent of societal pressures when it comes to determining the raw materials and energy resources that are allowed to be imported. Similarly, Moran (1978:264, quoted from Wilson 1987:138) argues that the models of economic maximization are not realistic and that they are misleading when applied to OPEC decision making; the most complete and powerful explanations were those acknowledging that "political and security concerns wag the economic tail, and not vice versa; where they conflict, the former prevail." 
The contribution of this line of literature, I argue, is in the field of US policy making. The authors illuminate how foreign policy decisions regarding energy markets in the US and OPEC countries are made. Their accomplishment is the combined analysis of political and economic factors that shape foreign policy decisions. The weakness of the literature is that, unlike regime theorists or structural realists, the research is not concerned with the overall distribution of power and capabilities in the international system. This, of course, allows researchers theoretical rigor, since they only conceptualize political processes. However, excluding the analysis of distribution of power within the international system weakens their analysis.

A second group that studied energy security from the perspective of domestic politics is public policy literature. These studies focused on practical problems when it comes to federal and state government policies concerned with energy security. Researchers analyzed various policy questions, like the nature of energy security policy making in the US's or EU's political system (Moe 1979; Matláry 1997); the tension between federalism and state-level policy making in the energy policy context (Light $1976 ; 1979)$; the nature of the relationship and negotiations between different federal agencies and inter-organizational conflicts on energy issues (Molnar and Rogers 1979; Burkardt et al. 1997); science and federal funding issues for energy research (Lambright 1998); and more at the macro level, discussions about expanding federal agencies and creating new organizations (e.g., High Energy Administration or the Energy Commission) to coordinate energy policies (Keenan 1968; Tribus 1975). These studies focus on domestic decision making, the administrative, coordination and financial sides of the issue, and tend to ignore the international side of the energy security coin.

\section{Regime Theory}

The regime theory focuses on political rules that shape economic relations and create the environment in which states and markets operate. The IPE literature has produced some important works that attempt to capture the political economic nature of energy security. The main premise that guided such analyses is the notion that economic systems do not emerge spontaneously but rest on a particular political order and exercise of power (Gilpin 2001).

The regime model presents energy crises and energy security issues from a perspective of international regimes, in which certain values, norms, expectations, and interdependent relations change the behavior of the actors. The most powerful actor in the regime (like a principal actor in the rational choice literature) provides public goods and positive benefits to the actors operating in the regime. According to this model, regimes change because the heft of the most powerful actor, or hegemon, has changed. Regime theorists, such as Keohane and Nye (1977), conceptualize the energy market crises of the 1970s in this context. Nye (2005) characterizes the pre-1973 international oil regime as one of a private oligopoly with close ties to the governments of the major industrialized consumer countries. After 1973, a major change took place in the international regime that governed oil. With the OPEC embargo and oil crisis, the producing countries set the level of production, which gave them a huge leverage on international politics and economics. According to Nye, this led to an enormous shift of power and wealth from the industrialized world to the relatively poor members of the international system; he does not think it was the OPEC act that led to this change, because OPEC had been established in 1960 and did not use production and exports as a weapon until 1973. Such a major change in the international oil regime can be explained by three factors: the overall balance of power, the balance of power concerning the oil issue, and the influence of international institutions (Nye 2005). 
First, the stability of the regime is altered owing to the decline of American power. For Nye (1982; 2005), the British withdrawal from the Persian Gulf and the US's reluctance - or incapacity - to fill the power vacuum in the region led to the breakdown of the international oil regime:

In summary, the loose regime that governed the oil market broke down in 1970s under the influence of catalytic political events and long-term shifts of power, not because of OPEC's formation or because of market forces alone. (Nye 1982:12)

Nye argues that America's reluctance to replace British forces "East of Suez" and trying to achieve foreign policy objectives via regional powers like Iran were mistakes that led to the 1973 and 1979 events. This is indeed a realist explanation of the 1973 and 1979 oil crises.

His second explanation employs a more modified realist account that focuses solely on the distribution of power within the oil issue itself, not just the overall military balance. This line of argument suggests that the international oil regime went through substantial changes: The US was the largest oil producer until 1971 when its production peaked, leading to a substantial increase in its oil imports. During the 1956 and 1967 wars, the Arab states attempted to pursue an embargo that failed because the US was able to supply Europe with its surplus oil when the Arab states did not supply it. Once the US began importing oil in substantial amounts, the power balance was changed in favor of Saudi Arabia.

Lastly, Nye (2005) argues that international institutions, specifically multinational companies and OPEC, could be the reason for the change of the oil regime. That is, multinational companies (e.g., the seven sisters) lost power because local workers, engineers, and staff in the producing countries learned how to run the oil business. Therefore, multinational companies, influenced by Western governments, lost their bargaining power against oil-producing nations. OPEC's price control also became more influential because oil was not as abundant as in the preceding two decades. This gave OPEC more bargaining leverage and room to act like a genuine cartel.

Regime theorists also carried out an analysis of the effects of domestic actors on international regimes. Keohane (1984) demonstrates in what ways domestic actors prevented the inclusion of cheap Middle Eastern oil on American markets, which led the US to be more vulnerable to the price shocks of the 1970s. This is a clear example of how domestic factors can affect international regimes, or how oil independents (smaller independent energy companies) harmed the energy security of the US.

The strength of this literature lies in its emphasis on the political influences on energy markets. As Gilpin (2001) suggests, markets do not operate in a vacuum. This literature successfully shows that there are rules and regulations that adjust market behavior and also that states intervene in the markets when they perceive market failures. This line of literature, however, can be criticized, as well, because it fails to draw analytic linkages between markets and regimes. Deese (1979-80), Deese and Nye (1981), and Wilson (1987) argue that more attention should be paid to identifying and analyzing specific political mechanisms that affect energy markets. Also, the boundaries between markets in general and energy markets in particular are not clearly drawn. This objection appears legitimate, especially if one takes into account the specific arrangements of energy markets and the security dimension for the states.

\section{Resource Conflict Literature}

In the early $1980 \mathrm{~s}$, with a decline of various resources in the world and the problems associated with the markets distributing them, literature on global resource scarcity 
has begun to emerge. These studies are, of course, not the first to theorize about resource scarcity. Thomas Robert Malthus (1766-1834), a British political economist, wrote more than two centuries ago in An Essay on the Principles of Population (1798) that the "population increases in a geometric ratio, while the means of subsistence increases in an arithmetic ratio." Exponential population growth and environmental degradation, in his opinion, will lead to inevitable conflicts over natural resources between nations:

For the principle of population will still prevail, and from the comfort, ease and plenty that will abound, will receive an increasing force and impetus. The number of mouths to be fed will have no limit; but the food that is to supply them cannot keep pace with the demand for it; we must come to a stop somewhere, even though each square yard, by extreme improvements in cultivation, could maintain its man. In this state of things there will be no remedy; the wholesome checks of vice and misery (which have hitherto kept this principle within bounds) will have been done away; the voice of reason will be unheard; the passions only will bear sway; famine, distress, havoc and dismay will spread around; hatred, violence, war and bloodshed will be the infallible consequence; and from the pinnacle of happiness, peace, refinement and social advantage we shall be hurled once more into a profounder abyss of misery, want, and barbarism than ever by the sole operation of the principle of population! (Malthus 1798)

In times which were so euphoric about the future of mankind (i.e., during the Enlightenment), Malthus's view was rather pessimistic but perhaps more realistic, for toward the end of the twentieth century the world witnessed famines (e.g., in Africa or Asia), resource crises, such as the energy crisis in the 1970s, and serious environmental problems like global warming.

The literature on transnational resource conflicts focused on the reasons and remedies for resource conflicts. Researchers showed that there is yet another form of non-violent conflict but also pointed out that they can turn violent in the near future (Choucri 1974; Choucri and North 1975; Russett 1981-2; Kemp 1978; Bannon and Collier 2003; Trolldalen 1992; Le Billon 2005; Klare 2001). There is also a part of the literature on resource conflict at the domestic level that substantially contributed to our understanding of resource conflicts in general, such as Gurr (1985), Reuveny and Maxwell (2001), and Ross (2004a; 2004b).

Robert Mandel $(1980 ; 1988)$ suggests that global resource scarcity has led to an increase of non-violent resource conflicts on the international level. He focuses on a wide range of resource conflicts, related not only to fossil fuels but also to other resources, such as whaling (between the US, Japan, and the USSR), food (grain conflict between the US and the USSR), strategic non-fuel minerals (such as chrome, manganese, cobalt), and environmental pollution and nuclear disasters (e.g., Chernobyl).

Mandel (1980:101) describes a framework of factors that determine the occurrence of transnational conflicts: 1) A decreasing and inelastic resources supply on the global, rather than national or local level; 2) an increasing or constant inelastic demand for these resources on a global, rather than national or local level; 3) a change of global resource access compared to the earlier period where unrestricted access to resources by some nations caused their inequitable distribution; 4) an increasing significance of collective or common pool resources, rather than private or nationally monopolized resources; 5) an increase in spillover effects of one nation's resource policy on others; 6) an increase in the complex structures of international interdependence when extracting, processing, and distributing resources; and 7) an increased impact of transnational and nongovernmental forces, such as Greenpeace, in determining the use of resources.

According to Mandel (1980; 1988), Choucri and North (1975), Kemp (1978), Campbell (1977), and Russett (1981-2), the fact that the markets cannot distribute 
resources as well as they used to causes different patterns of conflict in international politics. These patterns can be evaluated by analyzing the interests and strategies of different stakeholders. First, as a result of the conflict, industrial states with more military capabilities tend to use those capabilities for economic gain. That is, powerful industrial states tend to initiate conflicts to satisfy their citizens' insatiable demands and maintain economic growth. Second, the weaker producing states start bonding to counteract the impact of industrialized countries or their companies with the goal of achieving a redistribution of scarce resources. Third, the non-state actors, like conservationist groups, become involved in natural resource policy making.

This line of literature can take credit for facilitating the definition of the problem of transnational resource conflicts. It effectively highlighted the problem in the early 1970 s and brought to attention the way it evolved by theorizing about the relationship between markets, states, and non-state actors. However, the literature's skeptical propositions about the industrialized states' conflict initiation cannot be confirmed when reviewing wars in energy-rich regions in the past three decades. Other than the 2003 Iraq War, the conflicts in these regions were generally started by an industrializing state or states. Their hypothesis that industrialized states will initiate conflicts to maintain their economic growth rate does not correspond with these cases.

\section{National Energy Security and Foreign Policy Literature}

The examples from this line of the literature are fairly similar in their conceptualization of the subject; however, there are fine differences in their scope and emphasis of prescriptions. One branch of this literature is military security oriented and focuses on the implications of energy security on armed conflict, while another branch emphasized regional and global proactive foreign policy making to ensure the security of supply to markets.

Russett (1981-2) asks the important question whether history will repeat itself if security and resources decline. He draws parallels between 1914 and 1984 and speculates about the possibility of a military confrontation between the US and the USSR in the Middle East over natural resources, especially oil. He argues that the risks of a confrontation of international great powers over resources will be fairly possible in the 1980s. In retrospect, his predictions did not come true, owing to the decline of the Soviet Empire in the late 1980s. The 1990s witnessed a fairly stable international oil regime, as well. However, in the new millennium, the demand for energy hit a peak that caused great-power rivalry, if not conflict, in the Caspian, Eastern, and Central European regions between the US and Russia, as well as the EU and Russia.

Copaken (1995) gives an excellent explanation of oil as a strategic commodity, similar to Russett's, by evaluating the cases of Japan (1930-41) and World War II for all actors involved, especially focusing on Japan, Germany, and the Middle East since the outbreak of World War II. Similar studies (Kemp 1978; Campbell 1977) focused on changes in the balance of power and producer-consumer relations in the Middle East. John C. Campbell (1977) argues that the events of the 1970s made Iran and Saudi Arabia much more powerful than they ever expected to be, which changed their relations with the Western industrialized world. Although he stresses the changed dynamics of the relations between those two groups of countries and asserts that Western economies are defenseless against producers, he correctly points out the internal, regional, and international vulnerabilities of the producing nations and does not forecast a full-scale confrontation. He suggests that Western nations cannot use force to take over oil fields without causing a great stir in the Middle East, while producers cannot push consumers too much without harming themselves. In retrospect, his analysis holds valid: Since the 1973 oil crisis, there has not been a single concerted effort from OPEC to substantially disrupt the flow of oil or gas. 
Geoffrey Kemp (1977-8), on the other hand, evaluates the energy security-foreign policy relationship from a military intervention point of view and categorizes the possible types of military intervention needed to ensure energy security for the US. He argues that there are three major types of military intervention that might be required:

First, military conflict to control, destroy or protect a given resource, such as an oil field, a watershed, fishing areas, arable land or precious mineral areas; second, military deployments to annex or protect a land or sea area believed to contain or to be close to potentially valuable resources such as offshore islands near oil-bearing rock formations; third, military conflict that affects access routes to and from sources of supply - sea, air and land lines of communication, especially straits, and airstrips, railroad systems and ports. (Kemp 1978:413)

Kemp argues that the sources of contention in each case might or might not be energy resources per se. He distinguishes between cases where resource conflict is the primary reason for disagreements, as in the Anglo-Icelandic Cod War, and cases where oil is a secondary concern for both parties, albeit potentially catalytic, as in the Greek-Turkish conflict over Aegean Sea oil exploration. In a similar study, David L. Weimer (1995) reaffirms the importance of the relationship between petroleum and national security and proposes specific remedies to diminish US military dependence by strategic stockpiling.

Charles Doran, one of the pioneers of energy security research, challenges the myths surrounding the relationships between the oil industry, markets, OPEC, governments, militaries, and the Middle East (Doran 1977; 1980; Doran and Buck, 1991). In Myth, Oil and Politics: An Introduction to the Political Economy of Petroleum (1977), Doran refutes six different "myths" that surround oil as a strategic commodity. These myths include: the existence of inequitable (or unfair) oil prices; Israel and Middle Eastern wars being reasons for high oil prices; obscene corporate profits due to high prices; the necessity of divesting major oil companies to break their power; the idea that the International Energy Agency created a consumer program capable of making a stand against OPEC and others; and that OPEC members will act cohesively as a cartel to control international market prices. Doran disproves these myths by showing that they are based on inaccurate and incomplete information and false assumptions about the politics and economics of oil. However, Doran is not quite clear about who actually subscribes to these myths (e.g., governments, media, consumers, international actors), how they affect US policy making, and the remedies he suggests (such as international cooperation to replace the IEA). The most important achievement of this book is that it falsifies the six outlined myths and makes a sound introduction to the political economy of oil markets. That is, Doran successfully combines political and economic variables in addressing the research question.

Finally, a part of the energy literature emphasizes the importance of foreign policy making in achieving energy security goals. These studies do not exclude domestic factors that are major components of the energy security of a country, such as domestic investments, deregulated markets, and strategic reserves. However, they strongly emphasize the role of foreign policy making to guarantee the supply for their domestic markets (Stobaugh and Yergin 1979; Schlesinger 2005; Hamilton 2005; Kalicki and Goldwyn 2005a; Sieminski 2005; Yergin 2005).

The incorporation of both the domestic and foreign side of the energy security coin in their analysis is one of the greatest strengths of this literature. Its conceptualization of energy security is more comprehensive than that of any other stream of literature discussed above. Daniel Yergin (2005), for example, proposes that energy security has 10 key principles of importance. These can be briefly summarized as follows: 1) Diversification of supply, 2) stability of the global energy markets, 3) spare 
capacity (e.g., strategic petroleum reserves), 4) freer market - fewer regulations, 5) building cooperative relations with producer and exporting countries, 6) dialogue and cooperative relations with consumer nations, 7) a proactive security framework, including foreign policy that prevents disruptions of the entire chain of supply, 8) a well-informed public, 9) a healthy, technology-driven energy industry, and 10) a commitment to research, development, and innovation across a broad spectrum.

In a large volume, Energy Security: Toward a New Foreign Policy Strategy, the editors Jan Kalicki and David Goldwyn (2005a) brought together the leading authorities on the subject in the US. The main conclusion of the volume is that energy concerns must be integrated into US foreign policy. They argue that the energy tail should not wag the foreign policy dog. The authors recommend that fundamental US policies, such as defense against threats like terrorism and the promotion of democratic, economic, and humanitarian objectives around the world, should not change. They rather suggest that energy is an increasingly important vehicle to advance these and other objectives.

Kalicki and Goldwyn (2005a:570) describe the "positive relationship among energy, foreign policy and national security" as concentric circles. The core circle symbolizes defense against the physical disruption of supply. The US economy and society depend on this supply. The second circle shows the strategic reserves to guard the domestic market under extreme pressures from producers or other disruptions, such as natural disasters. The next circle illustrates the use of energy resources to spur development, promote transparency, and help resolve conflicts. The fourth and last circle suggests using energy as an instrument to promote regional foreign policy objectives in producing regions in a way that reinforces - and is reinforced by - the other three circles.

This framework of analysis suggests that the US will face four major challenges in foreign policy issues related to energy security, which are "building alliances, strengthening collective energy security, asserting its interests with energy suppliers, and addressing the rise of state control in energy" (Kalicki and Goldwyn 2005b:571). These foreign policy challenges will require solid responses from the US government. Kalicki and Goldwyn (2005b) explain the necessary foreign policy responses in detail. They determine eight specific foreign policy responses that are required to overcome the explained challenges.

The following two of the eight policy responses constitute the core relationship between energy security and foreign policy making. The authors suggest that the first component of the new foreign policy described is "candor and respect" for the producer countries. They argue that US policy makers avoid criticizing producer governments for fear of threatening their relations with them and therefore put the US's energy security at risk. The authors claim that the US has been too silent on Africa's kleptocracy, Russia's trespasses on the rule of law, and repressive, undemocratic governments in the Middle East. Their suggestion is to criticize the producing countries in the international arena and penalize them if necessary. This aspect of foreign policy most concerns the Middle East. According to this perspective, most governments in the Middle East repress their people and some of them, like Iran, threaten stability in the region. American foreign policy, according to the authors, should challenge these kinds of threat. Second, America needs foreign policies that promote the stability and security of its suppliers. That is, the US should intervene in regional conflicts to provide stability and security to the ally suppliers such as Azerbaijan or Georgia.

Similarly, the European Union has become concerned with energy security in the past decade. The research conducted and funded by the EU Commission and the EU Council produced various important documents and studies that benefited the literature, such as Study on Energy Supply Security and Geopolitics (2004), Green Paper - Towards 


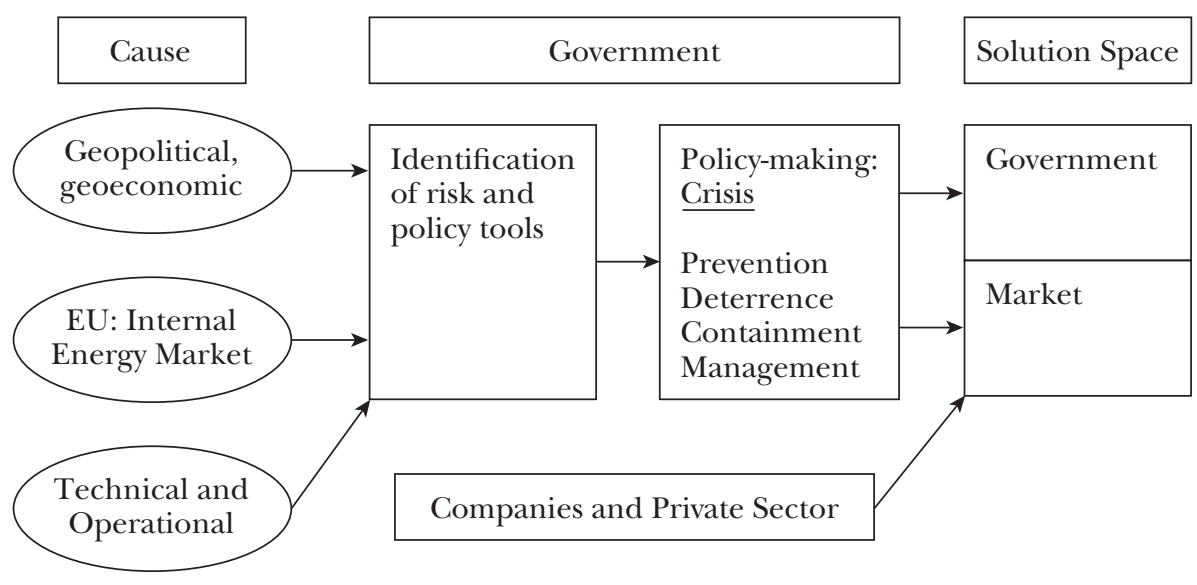

Figure 2 Schematic representation of policy tools (adapted from Study on Energy 2004)

a European Strategy for the Security of Energy Supply: Technical Document (2000), Communication from the Commission to the Council and the European Parliament: Final Report on the Green Paper (2002). In Study on Energy (2004:15), the primary result of the research is fairly similar to the one described by Kalicki and Goldwyn's (2005b) energy security strategy for the US: “. . . energy must become an integral part of EU external trade and foreign and security policy making. EU foreign and security policy and external trade policy are crucial energy policy tools to achieve future security of supply."

Figure 2 shows that when a producer country or region is unstable, the primary tool for the EU is prevention by foreign policy making. In this context, when a producing or transit country or region is stable, the EU's policy tool is prevention; when unstable, the policy tools are prevention, containment and deterrence; when in turmoil, containment and crisis management are the available foreign policy tools for the EU.

This review of the national energy security-foreign policy linkages works focuses on a rather state-centered literature owing to the dominance of such studies in the field and space limits. However, it is necessary to remind the reader that there is a growing new economic, environmental, and absolute gains perspective that deals with questions such as challenges raised by sustainable development, greening development, climate debate and fossil fuels, human security, energy availability for transnational corporations, and energy security-technology relationships (Klare 2008; Howell and Nakhle 2007; Herrera 2006; International Energy Agency 2007). To sum up, all streams of literature suggest that energy security must be a fundamental part of US and EU foreign policies. Along with more recent discussions about energy-economics-climate-human security relations, the traditional literature suggests that the most efficient way to handle threats to the supply chain is the application of proactive international policies that prevent instability in energy-rich regions.

\section{A Discussion of Theorizing}

Table 1 shows how different theories in the existing energy security literature conceptualize the most important variables for providing energy security for a state. The neoclassical economic approach asserts that markets are the sole factors shaping energy market stability; it also recognizes the domestic and international side of the 
Table 1 Theoretical and policy implications of three models. (Policy implications part is adapted from Wilson 1987)

\begin{tabular}{|c|c|c|c|c|c|c|}
\hline & \multicolumn{3}{|c|}{ Key Variable(s) } & \multicolumn{3}{|c|}{ Policy Implications } \\
\hline & Markets & $\begin{array}{c}\text { Political } \\
\text { Processes, Elite } \\
\text { decision making, } \\
\text { Domestic actors. }\end{array}$ & Structural & $\begin{array}{l}\text { Foreign or } \\
\text { Domestic } \\
\text { Issue }\end{array}$ & $\begin{array}{l}\text { Influence } \\
\text { (of states) }\end{array}$ & Tools \\
\hline $\begin{array}{l}\text { Neoclassical } \\
\text { Economics }\end{array}$ & Yes & No & No & $\begin{array}{l}\text { Both; } \\
\text { more } \\
\text { domestic }\end{array}$ & $\begin{array}{l}\text { Very } \\
\text { limited }\end{array}$ & $\begin{array}{l}\text { No } \\
\text { intervention } \\
\text { needed }\end{array}$ \\
\hline $\begin{array}{l}\text { Public } \\
\text { Choice }\end{array}$ & Yes & Yes & No & Both & Limited & Variety \\
\hline $\begin{array}{l}\text { Regime } \\
\text { Theory }\end{array}$ & No & Yes & Yes & $\begin{array}{l}\text { Foreign } \\
\text { policy }\end{array}$ & $\begin{array}{l}\text { Large but } \\
\text { declining }\end{array}$ & $\begin{array}{l}\text { Variety, both } \\
\text { oil and } \\
\text { non-oil }\end{array}$ \\
\hline $\begin{array}{l}\text { Policy/ } \\
\text { Political } \\
\text { Model }\end{array}$ & Limited & Yes & No & Both & $\begin{array}{l}\text { Potentially } \\
\text { large }\end{array}$ & $\begin{array}{l}\text { Diplomacy, } \\
\text { persuasion }\end{array}$ \\
\hline $\begin{array}{l}\text { Resource } \\
\text { Conflict } \\
\text { Lit. }\end{array}$ & Yes & Yes & $\begin{array}{l}\text { Depends } \\
\text { on study }\end{array}$ & Both & $\begin{array}{l}\text { Potentially } \\
\text { large }\end{array}$ & $\begin{array}{l}\text { Variety, } \\
\text { international } \\
\text { cooperation } \\
\text { emphasized }\end{array}$ \\
\hline $\begin{array}{l}\text { Foreign } \\
\text { Policy } \\
\text { Energy Sec. } \\
\text { Connection } \\
\text { Lit. }\end{array}$ & Yes & Yes & Yes & Both & $\begin{array}{l}\text { Potentially } \\
\text { large }\end{array}$ & $\begin{array}{l}\text { Variety, } \\
\text { mainly } \\
\text { foreign } \\
\text { policy }\end{array}$ \\
\hline
\end{tabular}

issue and argues that state intervention is useless. Policy models are the most useful regarding the analysis of political and economic factors in a synthesized way and identifying the influence of states and diplomacy. This approach, however, does not incorporate how the systemic characteristics of international relations at the time of decision making contribute to policy making. Regime theorists, on the other hand, incorporate domestic and structural realities of foreign policy decision making, yet cannot incorporate the influence of market actors into the analysis of decision making.

The literature on transnational resource conflict is most useful in terms of defining the nature of the problem; however, its propositions about the behavior of great powers, both among themselves and against the developing producer countries, did not appear to be valid. Its emphasis on the increased role of nongovernmental organizations does not reflect the realities of international politics. Alternatively, the literature on the relationship between energy, national security, and foreign policy incorporates the most important variables that energy security research should include, as Table 1 indicates.

The basic problem with energy security literature lies in its exclusive dependence on case studies, personal accounts, and policy prescriptions from professionals. That is, these studies do not seem to benefit from the advancements regarding foreign policy-domestic policy linkages and analyses in the political science literature. They focus on some specific foreign policy goals that they believe the industrialized states should pursue. They lack advanced theoretical and methodological analyses. 
The literature on energy security, despite its problems, has its strengths. There are a few propositions that the current literature on energy security seems to agree upon, albeit not entirely. They are briefly outlined below.

Proposition 1: Important externalities exist in the international energy markets that create problems for the functioning of the markets without intervention (Cornes and Sandler 1996).

Proposition 2: Government intervention is necessary to mitigate the effects of these externalities in the energy markets (Bohi and Toman 1996).

Proposition 3: Foreign policy as a necessary and integral part of the EU's and US's energy policies must be used proactively to prevent disruptions of the entire chain of energy supply (Kalicki and Goldwyn, 2005a; 2005b).

Proposition 4: Until 2020, there will not be physical shortages of oil and gas in the global energy markets; any disruption will arise from political problems for trade, production, and investment in oil and gas industries (Study on Energy 2004).

Proposition 5: In the next 20 years, it will not be possible for the US and EU to replace the existing energy trade and security links with Middle Eastern producing nations (Kalicki and Goldwyn 2005a).

Proposition 6: Russia and the Caspian regions can provide Western economies with supply diversity. Thus the US and EU should prevent political turmoil in the region by proactive foreign policy (Nanay 2005; Study on Energy 2004).

Using these propositions to produce testable hypotheses and build a theoretically engaging energy security literature can be a good starting point for scholars who will invest in the field.

\section{References}

Adelman, M.A. (1972) The World Petroleum Market. Published for Resources for the Future. Baltimore: Johns Hopkins University Press.

Adelman, M.A. (1974) Politics, Economics, and World Oil. The American Economic Review $64,(2), 58-67$.

Adelman, M.A. (1980) OPEC the Clumsy Cartel. The Energy Journal 1 (1), 43-52.

Adelman, M.A. (1990) Mineral Depletion, with Special Reference to Petroleum. Review of Economics and Statistics 72 (1), 1-10.

Adelman, M.A. (2004) The Real Oil Problem. Regulation 27 (1), 16-21.

Bannon, I., and Collier, P. (eds.) (2003) Natural Resources and Violent Conflict: Options and Actions. Washington: World Bank.

Barton, B., Redgwell, C., Ronne, A., and Zillman, D.N. (eds.) (2004) Energy Security: Managing Risk in a Dynamic Legal and Regulatory Environment. Oxford: Oxford University Press.

Bohi, D.R., and Toman, M.A. (1995) Oil and National Security: An Assessment of Externalities and Policies. In S. Shojai (ed.) The New Global Oil Market: Understanding Energy Issues in the World Economy. Westport: Praeger, pp. 203-16.

Bohi, D.R., and Toman, M.A., with a contribution by Walls, M.A. (1996) The Economics of Energy Security. Boston: Kluwer Academic.

Bohi, D.R.W., and Montgomery, D. (1982) Oil Prices, Energy Security, and Import Policy. Published for Resources for the Future. Baltimore: Johns Hopkins University Press.

Brennan, M.J. and Schwartz, E.S. (1985) Evaluating Natural Resource Investments. The Journal of Business 58 (2), 135-57.

Broadman, H.G., and Hogan, W.W. (1988) Numbers Say Yes (Special Feature: Is an Oil Tariff Justified? An American Debate). Energy Journal 9 (3), 7-29.

Burkardt, N., Lamb, B.L., and Taylor, J.G. (1997) Power Distribution in Complex Environmental Negotiations: Does Balance Matter? Journal of Public Administration Research and Theory 7 (2), 247-75.

Campbell, J.C. (1977) On Power: Oil Power in the Middle East. Foreign Affairs Oct. Washington: Council on Foreign Relations. 
Choucri, N. (1974) Population Dynamics and International Violence: Propositions, Insights and Evidence. Lexington: D.C. Heath/Lexington Books.

Choucri, N. and North, R.C. (1975) Nations in Conflict: National Growth and International Violence. San Francisco: W.H. Freeman.

Communication from the Commission to the Council and the European Parliament. (2002) Final Report on the Green Paper "Towards a European strategy for the security of energy supply". Brussels, 26 June. COM(2002) 321 Final.

Copaken, R.R. (1995) Oil as a Strategic Commodity. In S. Shojai (ed.) The New Global Oil Market: Understanding Energy Issues in the World Economy. Westport: Praeger, pp. 217-24.

Cornes, R., and Sandler, T. (1996) The Theory of Externalities, Public Goods, and Club Goods, 2nd edn. Cambridge: Cambridge University Press.

Deese, D.A. (1979-80) Energy: Economics, Politics and Security. International Security 4 (3, Winter), pp. 140-53.

Deese, D., and Nye, J. (eds.) (1981) Energy and Security. Cambridge: Ballinger.

Deffeyes, K. (2005) Beyond Oil: The View from Hubbert's Peak. New York: Hill and Wang.

Dixit, A.K. and Pindyck, R.S. (1994) Investment under Uncertainty. Princeton: Princeton University Press.

Doran, C.F. (1977) Myth, Oil, and Politics: Introduction to the Political Economy of Petroleum. New York: Free Press.

Doran, C.F. (1980) OPEC Structure and Cohesion: Exploring the Determinants of Cartel Policy. The Journal of Politics 42 (1), 82-101.

Doran, C.F., and Buck, S.W. (eds.) (1991) The Gulf, Energy, and Global Security: Political and Economic Issues. Boulder: L. Rienner.

Eastwood, R.K. (1992) Macroeconomic Impacts of Energy Shocks. Oxford Economic Papers, New Series 44 (3), 403-25.

Gilpin, R. (2001) Global Political Economy: Understanding the International Economic Order. Princeton: Princeton University Press.

Green Paper - Towards a European Strategy for the Security of Energy Supply: Technical Document. (2000). Brussels: European Commission.

Green Paper: Towards a European Strategy for the Security of Supply. (2000). [29 November 2000 (COM (2000) 769 Final)]. Brussels: European Commission.

Greenberger, M. (1983) Caught Unawares. Cambridge: Ballinger.

Griffin, J.M. (1985) OPEC Behavior: A Test of Alternative Hypotheses. American Economic Review $75,954-63$.

Gurr, T.R. (1985) On the Political Consequences of Scarcity and Economic Decline. International Studies Quarterly 29 (1), 51-75.

Hamilton, J.D. (1983) Oil and the Macroeconomy since World War II. The Journal of Political Economy 91 (2), 228-48.

Hamilton, L.H. (2005) Foreword. In J.H. Kalicki and D.L. Goldwyn (eds.) Energy and Security: Toward a New Foreign Policy Strategy. Washington: Woodrow Wilson Center Press, p. xxi.

Hancher, L., and Janssen, S. (2004) Shared Competences and Multi-Faceted Concepts - European Legal Framework for Security of Supply. In B. Barton, C. Redgwell, A. Ronne, and D.N. Zillman (eds.) Energy Security: Managing Risk in a Dynamic Legal and Regulatory Environment. Oxford: Oxford University Press, pp. 85-119.

Herrera, G. (2006) Technology and International Transformation: The Railroad, the Atom Bomb, and the Politics of Technological Change. New York: State University of the New York Press.

Hubbard, R.G. (1986) Supply Shocks and Price Adjustment in the World Oil Market. The Quarterly Journal of Economics 101 (1), pp. 85-102.

Howell, D., and Nakhle, C. (2007) Out of the Energy Labyrinth: Uniting Energy and the Environment to Avert Catastrophe. New York: I.B. Tauris.

International Energy Agency. (2007) Toward a Clean, Clever and Competitive Energy Future - IEA Report to G8 Summit in Heiligendamm, Germany 2007. Available at: www.iea.org/Textbase/ publications/free_new_Desc.asp?PUBS_ID=1920, accessed July 2, 2009.

James, P. (2002) International Relations and Scientific Progress: Structural Realism Reconsidered. Columbus: Ohio State University Press.

Kalicki, J.H., and Goldwyn, D.L. (eds.) (2005a) Energy and Security: Toward a New Foreign Policy Strategy. Washington: Woodrow Wilson Center Press. 
Kalicki, J.H., and Goldwyn, D.L. (2005b) Conclusion: Energy, Security and Foreign Policy. In J.H. Kalicki and D.L. Goldwyn (eds.) Energy and Security: Toward a New Foreign Policy Strategy. Washington: Woodrow Wilson Center Press, pp. 561-78.

Keenan, B.R. (1968) High Energy Administration: Big Science Model for the Future? Public Administration Review 28 (3), 250-5.

Kemp, G. (1978) Scarcity and Strategy. Foreign Affairs Jan. Washington: Council on Foreign Relations.

Kennedy, M. (1974) An Economic Model of the World Oil Market. Bell Journal of Economics and Management Science 5, 540-77.

Keohane, R. (1984) After Hegemony: Cooperation and Discord in the World Political Economy. Princeton: Princeton University Press.

Keohane, R.O., and Nye, J.S. (1977) Power and Interdependence: World Politics in Transition. Boston: Little, Brown.

Kibritçioğlu, A., and Kibritçioğlu, B. (1998) Inflationary Effects of Increases in Crude and Fuel Oil Prices in Turkey (in Turkish). Paper presented at the International METU Conference on Economics Economic Research Center, Middle East Technical University, Ankara, September $9-12$.

Klare, M. (2001) Resource Wars: The New Landscape of Global Conflict. New York: Metropolitan Books.

Klare, M.T. (2008) Rising Powers, Shrinking Planet: The New Geopolitics of Energy. New York: Metropolitan Books.

Kleveman, L. (2003) The New Great Game: Blood and Oil in Central Asia. New York: Grove Press.

Krasner, S. (1978) Defending the National Interest: Raw Materials Investments and U.S. Foreign Policy. Princeton: Princeton University Press.

Lambright, W.H. (1998) Downsizing Big Science: Strategic Choices. Public Administration Review $58(3), 259-68$

Le Billon, P. (ed.) (2005) Geopolitics of Resource Wars: Resource Dependence, Governance and Violence. Geopolitics. London: Frank Cass.

Light, A.R. (1976) Federalism and the Energy Crisis: A View from the States. Publius. The States as Keystones: A Bicentennial Reassessment 6 (1), 81-96.

Light, A.R. (1979) The Legislated Role of the States in the National Energy Acts. Publius. The State of American Federalism 9 (1), 188-89.

MacAvoy, P. (1982) Crude Oil Prices as Determined by OPEC and Market Fundamentals. Cambridge: Ballinger.

Malthus, T. (1798) An Essay on the Principle of Population, as It Affects the Future Improvement of Society with Remarks on the Speculations of Mr. Godwin, M. Condorcet, and Other Writers. London: Printed for J. Johnson in St. Paul's Church-Yard, 1798. Rendered into HTML format by Ed Stephan, 10 Aug. 1997. Available at www.ac.wwu.edu/ stephan/malthus/malthus.0.html, accessed July 2, 2009

Mandel, R. (1980) Transnational Resource Conflict: The Politics of Whaling. International Studies Quarterly 24 (1), 99-127.

Mandel, R. (1988) Conflict over the World's Resources: Background, Trends, Case Studies, and Considerations for the Future. New York: Greenwood Press.

Matláry, J.H. (1997) Energy Policy in the European Union New York: St. Martin's Press.

Miller, L.B. (1977) Energy, Security and Foreign Policy: A Review Essay. International Security $1(4), 111-23$.

Miller, M., and Zhang, L. (1996) Oil Price Hikes and Development Triggers in Peace and War. The Economic Journal 106 (435), 445-57.

Moe, R.C. (1979) Government Corporations and the Erosion of Accountability: The Case of the Proposed Energy Security Corporation. Public Administration Review 39 (6), 566-71.

Molnar, J.J., and Rogers, D.L. (1979) A Comparative Model of Interorganizational Conflict. Administrative Science Ouarterly 24 (3), 405-25.

Moran, T.H. (1978) Oil Prices and the Future of OPEC: the Political Economy of Tension and Stability in the Organization of Petroleum Exporting Countries. Washington: Resources for the Future.

Nanay, J. (2005) Russia and the Caspian Sea Region. In J.H. Kalicki and D.L. Goldwyn (eds.) Energy and Security: Toward a New Foreign Policy Strategy. Washington: Woodrow Wilson Center Press, pp. 127-47. 
Nye, J. (1982) Energy and Security in the 1980s. World Politics 35 (1), 121-34.

Nye, J. (2005) Understanding International Conflicts: an Introduction to Theory and History. New York: Pearson/Longman.

Redgwell, C. (2004) International Energy Security. In B. Barton, C. Redgwell, A. Ronne, and D.N. Zillman (eds.) Energy Security: Managing Risk in a Dynamic Legal and Regulatory Environment. Oxford: Oxford University Press, pp. 17-46.

Reuveny, R., and Maxwell, J.W. (2001) Conflict and Renewable Resources. The Journal of Conflict Resolution 45 (6), 719-42.

Ross, M. (2004a) How Does Natural Resource Wealth Influence Civil Wars? Evidence from Thirteen Cases. International Organization 58, 35-67.

Ross, M. (2004b) What Do We Know About Natural Resources and Civil War? Journal of Peace Research 41 (3), 337-56.

Russett, B. (1981-2) Security and the Resources Scramble: Will 1984 Be Like 1914? International Affairs 58 (1), 42-58.

Schlesinger, J.R. (2005) Foreword. In J.H. Kalicki and D.L. Goldwyn (eds.) Energy and Security: Toward a New Foreign Policy Strategy. Washington: Woodrow Wilson Center Press, p. xiii.

Sieminski, A.E. (2005) World Energy Futures. In J.H. Kalicki and D.L. Goldwyn (eds.) Energy and Security: Toward a New Foreign Policy Strategy. Washington: Woodrow Wilson Center Press, pp. 21-50.

Stobaugh, R., and Yergin, D. (1979) Energy future. A report of the energy project at the Harvard Business School. New York: Random House.

Study on Energy Supply Security and Geopolitics. (2004) Prepared for the European Commission and DG Transport and Energy by the Clingendael International Energy Programme (CIEP) and Clingendael Institute for International Relations.

Tribus, M. (1975) The Case for an Energy Commission. Public Administration Review 35 (4), 317-22.

Trolldalen, J.M. (1992) International Environmental Conflict Resolution: The Role of the United Nations. New York: UNITAR.

Weimer, D.L. (1995) Petroleum and National Security. In S. Shojai (ed.) The New Global Oil Market: Understanding Energy Issues in the World Economy. Westport: Praeger, pp. 225-38.

Wilson, E.J. (1987) World Politics and International Energy Markets. International Organization $41(1), 125-49$.

Yergin, D. (2005) Energy Security and Markets. In J.H. Kalicki and D.L. Goldwyn (eds.) Energy and Security: Toward a New Foreign Policy Strategy. Washington: Woodrow Wilson Center Press, pp. 51-64.

\section{Online Resources}

Energy Information Administration. At www.eia.doe.gov/, accessed July 1, 2009.

International Energy Agency. At www.iea.org/, accessed July 1, 2009. Official energy statistics from the US government. Various topics included.

OPEC. At www.opec.org/home/, accessed July 1, 2009. Website of the intergovernmental organization. Online library and oil markets reports.

OAPEC. At www.oapecorg.org/, accessed July 1, 2009. Website of the Organization of Arab Petroleum Exporting Countries. Provides publications, statistics, databank and information on regional cooperation.

OECD Observer. At www.oecdobserver.org/news/categoryfront.php/id/1142/Energy.html, accessed July 1, 2009. Website of the OECD Observer magazine. Provides information about today's economic and social challenges including energy and sustainable development.

Platts. At www.platts.com/, accessed July 1, 2009. Energy market news, stories and information, usually most up to date. 
World Energy Outlook. At www.worldenergyoutlook.org/, accessed July 1, 2009. An International Energy Agency publication. One of the authoritative sources on energy statistics in the world. Publications and policy database.

BP Statistical Review of World Energy. At www.bp.com/productlanding.do? categoryId= $6929 \&$ contentId=7044622, accessed July 1, 2009. Free quantitative data on fundamentals of the energy markets. Also historical data available.

\section{About the Author}

Özgür Özdamar graduated from the University of Missouri at Columbia in 2006. Since then he has worked at the University of Economics and Technology in Ankara and is now an assistant professor there. His research focuses on foreign policy analysis, IR theory, and energy security and he has published 12 scholarly articles. He currently serves as a member of ISA's FPA Section Executive Council. 